\title{
Proposed Technology Solutions for Special Educational Needs (SEN) Learners: Towards Inclusive Education in Malaysian Universities
}

\author{
Roslinda Alias, Nor Aziah Alias, Abu Bakar Ibrahim, and Jamizan Jalaluddin
}

\begin{abstract}
Inclusive Education in Malaysia is not a new agenda. It started in the 1990's in which at the beginning, this movement was focused on the special educational needs (SEN) learners. This movement is in line with the Education Act 1996 and other world declarations related to persons with disabilities (PWDs). For instance, the World's Declaration on Education for All (1992), the Salamanca Statement and Framework for Action on Special Needs Education (1994), as well as Biwako Millenium Framework for Action: Towards an Inclusive, Barrier-Free and Rights-based Society for Persons with Disabilities in Asia and the Pacific (2002). In addition, the introduction of the Person with Disabilities Act 2008 which highlighted the equal opportunity in education for SEN learners from pre-school up to tertiary level strengthened the inclusive education movement. Despite all, still SEN learners still faced barriers and challenges at universities as when they further their studies at the tertiary level, their welfare and needs are solely within the care of the individual university they enroll in. In this paper, several technologies are proposed as solutions to help SEN learners not only to survive, but also thrive at the tertiary level particularly university. Several options are put forward such as the use of tablets, the improvement of learning management system as well as the utilization of Web 2.0 in teaching and learning.
\end{abstract}

Index Terms-Assistive technology, inclusive education, special educational needs, university.

\section{INTRODUCTION}

The former Prime Minister of Malaysia, Dr. Mahathir Mohammad in the year 1991 introduced the ultimate vision of Malaysia, the Vision 2020. The vision envisages that by the year 2020, Malaysia will become a fully developed country which includes the area of education. The important role of education in Malaysia could be seen through the agenda presented in all the Malaysia Plans, that is from the First Malaysia Plan 1966-1970 to the Tenth Malaysia Plan 2011-2015.

Furthermore, the seriousness of the government in education can be seen from the introduction of a new policy known as "Pendidikan Wajib" (Compulsory Education) in 2002. Beginning January 2003, a penalty of RM5000 is to be imposed on parents who do not send their child or children to

Manuscript received August 25, 2012; revised January 13, 2013.

Roslinda Alias, Nor Aziah Alias, and Abu Bakar Ibrahim are with Facultly of Education, Universiti Teknologi MARA, Malaysia (e-mail: roslindaphd1010@ gmail.com, noraz112@salam.uitm.edu.my, abuba710@salam.uitm.edu.my).

Jamizan Jalaluddin is with Academia Special Community Network at the Universiti Teknologi MARA (e-mail: jamizan08@yahoo.com). primary school [1]. This policy is to ensure that all Malaysians will get equal opportunity in education. This applies to both normal children and children or persons with disabilities (PWDs).

Persons with disabilities (PWDs) are defined as "those who have long term physical, mental, intellectual or sensory impairments which in interaction with various barriers may hinder their full and effective participation in society" [2].

Currently, seven classifications of disabilities identified to be included under PWDs category that are 1) visually impaired, 2) hearing impaired, 3) phyisically disabled, 4) mentally disabled, 5) learning disabilities, 6) speech impaired and 7) multiple disabilities [3].

\section{INCLUSIVE EDUCATION IN MALAYSIA}

Inclusive education means giving equal opportunity to all students in education "regardless of their physical, intellectual, social, emotional, linguistic or other conditions" [4].

In Malaysia, inclusive education movement started in the 1990 's in which it is more focused on special educational need students [5]. Special educational needs (SEN) students are defined as those who are "visually handicapped, or partially of fully deaf or suffer from the disability to learn" [1].

One of the aims of the inclusive education movement in Malaysia is to support the The Salamanca Statement and Framework for Action on Special Needs Education [4], World's Declaration on Education for All [6], The Dakar Framework of Action [7] and the Biwako Millennium Framework for Action [8].

The continuous efforts towards this movement could be seen from the Malaysian Education Development Master Plan 2006-2010, which emphasizes on the equity of education for all Malaysians including special educational needs students (SEN).

\section{INCLUSIVE EDUCATION IN MALAYSIAN UNIVERSITIES}

As as been stated before, Malaysia is among the countries that support the inclusive education movement. Hence, eligible SEN learners received equal opportunities to pursue their studies in higher education as has been highlighted in the Education Act 1996 [1], Persons with Disabilities Act [2] as well as Policies and Action Plans for Person with Disabilities [9].

However, still there are a lot of arising issues on SEN 
learners in Malaysian higher education particularly in universities. These issues could hinder SEN the success of inclusive practices in higher education.

Among the issues faced by SEN learners in universities are barriers and challenges in teaching and learning. These include negative attitudes, physical barriers as well as insufficient special learning materials for them as have been found in [10]-[15].

Negative attitudes could be in many forms including social discrimination, lack of awareness and traditional prejudices [4]. A study by [12] on the SEN learners at two institutions of higher learning in Malaysia found that among the challenges faced by SEN learners is their normal friends' attitudes. They found it difficult to make friends with normal students as most of the normal students try to avoid them. Similarly, in the study by [16], the SEN students felt disregarded by their normal friends.

On the contrary, research done by [10] showed attitudes and perceptions of non-SEN learners towards SEN learners in one university in Malaysia were moderately positive. In addition, awareness and support from lecturers, non-SEN friends as well as support staff is vital to ensure that the SEN learners could survive in higher education. Reference [11] discovered that some SEN learners received improper treatment and support from their lecturers, non-SEN friends and support staff due to their lack of awareness in handling and catering to the SEN needs. The findings from this studies are congruent with a study done by [15] on sixty-eight SEN learners from eight Malaysian public universities. Even though SEN learners reported to have good relationships with their lecturers, support staff and non-SEN friends but due to lack of awareness most of them do not know how to interact and deal with SEN learners [15].

In addition, physical barriers are also among the main challenges faced by the SEN learners in universities. A research carried out by [12] on SEN learners in one university in Malaysia showed that the participants complained about the "non-SEN friendly" environment of their institution. Similarly, [11] discovered that SEN learners in one of the Malaysian universities complained about the inaccessibility of physical infrastructure provided for them on campus. The result was very much congruent with the results of a study by [16] in which the facilities for SEN learners did not follow the recommended specifications which led to difficulties among the SEN learners. In addition, reference [14] in their study among seven SEN learners in Malaysian universities revealed that physical barrier such as non-friendly building for SEN is among the main challenges faced by SEN learners.

On top of that SEN learners in Malaysian universities also reported learning materials such as Braille-form notes, electronic notes and e-books provided are insufficient as in the research by [11] and [14]. Aside from that, [14] indicated that learning facilities specifically for SEN learners' needs in universities such as screen readers for the blind and partially sighted SEN-friendly classrooms for wheelchair users and SEN with mobility difficulty are also lacking.

In a study on the needs of SEN learners in higher education, [15] reported that the research participants highlighted three SEN learners' needs namely accessibility needs, psychosocial support needs and special facilities and services. Accessibility needs include physical accessibility such as barrier-free buildings and information accessibility for SEN learners. Special counselling services for SEN are among the psychosocial support needs requested by SEN. Besides, awareness programmes for academic and support staff as well as their non-SEN friends are also requested by the SEN learners to be held at the universities to promote better understanding of SEN issues. In the same research, [15] also stressed on improving university facilities and services to cater to the needs of SEN learners as part of providing special facilities and services for them.

\section{Assistive TeChNOLOGY FOR CREATING INCLUSIVE ENVIRONMENT IN UNIVERSITIES}

Technology could not be separated from the educational field in this so-called Information Age. There are various types of technologies which emerged in the special education field to be used to support the SEN learners inclusively and these technologies are known as Assistive Technology (AT).

United States of America is the only country that came out with the Assistive Technology Act of 1998 and this act was amended in 2004 [17]. According to the Act, Assistive Technology is divided into two categories i.e. assistive technology device and assistive technology service.

Assistive technology device refers to any device or tool that is used to help and improve the SEN person's functions in an educational setting. As defined by [17], assistive technology device refers to "... any item, piece of equipment, or product system, whether acquired commercially, modified, or customized, that is used to increase, maintain, or improve functional capabilities of individuals with disabilities". While the assistive technology service is defined as ".. any service that directly assists an individual with a disability in the selection, acquisition, or use of an assistive technology device" [17].

In the field of instructional technology, assistive technology device is also known as "hardware and software that is designed or can be used to support the needs of exceptional students" [18]. It is ranged from "low-tech" for instance the invention of wheelchairs to "high-tech" such as computers and other advanced softwares and hardwares [18].

Kentucky Assistive Technology Service Network categorized ten assistive technology devices categories and these include technologies for 1) vision, hearing, 2) speech 3) communication, 4) learning, cognition and developmental, 5) mobility, seating and positioning, 6) daily living, 7) environmental adaptations, 8) vehicle modifications, 9) computers and related such as software and hardware and 10) recreation, sport and leisure [19].

In addition, Microsoft Corporation is also putting their initiatives in dealing with the PWDs' issues by providing the compatible up-to-date and wide range of assistive technology products for additional accessibility [20]. Among the products offered in the market are alternative input devices, Braille embossers, keyboard filters, light signaler alerts, on-screen keyboards, reading tools and learning disabilities programs, refreshable Braille displays, screen magnifiers, screen readers, screen recognition programmes, speech 
synthesizers, talking and large-print word processors as well as TTY/TDD conversion modems [20].

\section{INCLUSIVE EDUCATION IN MALAYSIAN UNIVERSITIES: WHAT'S NEXT?}

Institutions of higher learning should be able to create an inclusive environment for all students so that nobody will be left behind in pursuing higher education. By creating an inclusive environment for learning, it will accommodate the SEN students to learn along with the normal students.

However, as has been discussed earlier, studies on SEN learners in Malaysian higher education by [10]-[15] showed that they encountered various challenges and barriers not only in teaching and learning aspects but also in accessibility. Furthermore, reference [13] found that, SEN learners faced the above mentioned barriers and challenges since their first day of enrollment at the university.

With reference to [15], the SEN learners identified three aspects of needs during their study at the universities namely accessibility needs, psychosocial support needs and special facilities and services for SEN. However, this does not portray that the Malaysian government has not put much effort to cater to their needs attentively. SEN learners urged the university authority to improve the existing facilities and services and to provide more of those facilities at the universities.

Besides improving existing physical facilities and services as well as adding up new SEN-friendly facilities and services, utilization of AT could not be denied in promoting barrier-free learning environment for SEN learners in higher education.

Hence, technology is one of the best solutions proposed to help SEN learners survive in their studies. As recommended by Zalizan Jelas, technology could not be separated from our daily lives and thus help the SEN learners in pursuing their studies in higher education (personal communication, June, 5 2012). Moreover, studies on the needs of SEN learners in Malaysian higher education by [11], [15] have proven that technology is essential for the SEN learners to survive in their studies at tertiary level.

There are varied ranges of technologies that could be utilized to provide an inclusive environment that is conducive for all students especially for SEN learners. Henceforth, we suggest the use of tablets, the improvisation of the existing learning management system (LMS) and the utilization of Web 2.0 in teaching and learning.

\section{A. Tablets for SEN Learners in Universities}

Among the latest IT development in Malaysia is the emergence of tablets such as i-Pad and tablets for Android such as Samsung Galaxy Tab in the market. Tablets has the potential of being a powerful tool in teaching and learning. One of its benefits is it provides a variety of applications that support learning and it promotes interactive experiences in the classrooms [21].

On top of that, the portability of the tablets enables students to use them everywhere and anytime and thus encourages and promotes collaboration among students and educators. Furthermore, university students could interact and meet online with their friends as well as their lecturers through education-focused social network [21]. Special blogs or special groups on Facebook can be created to encourage and improve the interaction among the students with their lecturers including the SEN learners.

In addition, one of the distinguished features of tablets is the built-in e-book application. SEN learners may benefit from e-book as it provides sensory rich interactive immersive reading experiences [21].

Hence, it is proposed that each SEN learners who enrolled at Malaysian higher education should be provided with the tablets on their first day of registration.

It was also suggested that several applications should be integrated in the tablets for SEN learners for instance e-map. E-map could provide accessibility information for SEN learners. These include wheelchair routes and Braille path/track, special facilities provided within the university buildings such as special lifts, special toilets, ramps and handle bars as well as disability parking lot. Hence, this will help SEN learners to plan ahead their routes to classroom, library or other buildings in the university compound. The research findings by [11], [15], [16] on the needs and challenges of SEN learners in higher education confirmed the fact that this application can work as useful guide.

Furthermore, besides its small and light features, tablets that are currently available in the market are equipped with SEN-friendly technologies. For instance, i-Pad by Apple Inc. provides special accessibility built-in features for the disabled (i.e. blind, partially sighted, hearing impaired and physical impaired) such as screen readers, e-books, wireless Braille displays, tactile physical buttons, large text function, visual alerts and large multi-touch displays [22]. Thus, tablets are suitable for SEN learners and will be a useful learning tool for them.

It is also recommended to provide the SEN learners with textbooks in e-book version. If this is not feasible to be implemented, at least the university would able to offer the e-books price at minimal charges. This will help the SEN a lot by reducing their burden in borrowing and carrying the thick text books as their mobility is limited. On top of that they will be able to do their course revision anywhere at any time without having to bring thick books with them.

\section{B. Improvement of Learning Management System (LMS)}

Learning management system (LMS) is "a bundled of resource tool that an institution purchase and use to create fully integrated online classroom" [23]. LMS provides knowledge and information accessibility for students especially SEN anywhere and anytime.

With some improvement, LMS could be one of the powerful tools to support and facilitate the SEN learners in universities. Common LMS contains current information on the courses enrolled by the students. It also enables lecturers to upload their teaching materials in various forms and at the same time allow students to download these materials. Besides, it encourages interaction between lecturers and students, between students and their friends too. By adding some special functions in LMS, it could be an SEN-friendly teaching and learning tool.

In addition, communication platform should be provided 
to connect all SEN learners at universities as one of the needs as urged by the SEN learners in higher education is social connectedness. One of the participants in the research conducted by [15] was stated that "university should hold special programmes for us (SEN learners) so that we will know our community (SEN learner community) better...". This could be done by creating a special group for SEN learners parked under LMS. An icon of special group appears once the system identified one student as a disabled. This will enable SEN learners to interact and support each other.

In addition, it is also suggested that the LMS should be able to notify the lecturers on the existence of SEN learners in their classes through automated notification. When lecturers know the presence of SEN learners in their classes, they will be more prepared in catering to the needs of SEN learners. This includes preparing SEN-friendly teaching methods, learning materials, assessments and others that are related to teaching and learning processes.

\section{Web 2.0 in Teaching and Learning}

Web 2.0 emerged in the early 2000's in which it is gradually replacing Web 1.0 that treated users as passive readers. Reference [24] highlighted "with the Web 2.0 data sharing the web also becomes a platform for social software that enables groups of users to socialise, collaborate, and work with each other".

One of the Web 2.0 relevant software that may benefit both lecturers and students in teaching and learning is called social software [24]. This software facilitates interactive discussion and enables information sharing among lecturers and students.

Blogs is one of the social software that could be used by lecturers to aid their teaching. Lecturers could create special blogs for the purpose of sharing information and discussion. Students are encouraged to participate by adding their comments in the blogs.

Besides, both lecturers and students regardless whether they are SEN or not could use media sharing services to improve teaching and learning processes. For instance, YouTube could be used by teachers to upload their lectures so that it will enhance students' understanding of the particular topics discussed as they can watch it repeatedly.

Meanwhile, social networks such as Facebook and MySpace could be a good teaching and learning tool because it offers online interaction among lecturers and students. Due to its popularity among students, special group could be created on Facebook to promote interaction and discussion.

In addition to that, lecturers should encourage their students to use collaborative editing tools such as Google Docs in doing their assignments. This can save their time, money and energy since they can work together virtually.

Hence, if the lecturers could use these applications creatively, not only SEN learners but also non-SEN learners may benefit too.

\section{CONCLUSION}

It is undeniable that technology plays vital roles particularly for SEN learners in Malaysian higher education. However, not all the above suggestions could be materialized easily as there are a lot of barriers and challenges to be considered at the implementation stage.

First of all, currently, there is no special policy on the rights of SEN learners in Malaysian higher education even when the PWDs enter the Institutes of Higher Learning (IHL) to further their education; their welfare and needs are solely under the individual IHL. Currently, the administration of the PWDs in IHLs is not centralized under the Ministry of Higher Learning therefore, different IHLs have different approaches towards the PWDs (Salmah Zainal Abidin, personal communication, May 10, 2011). Besides that, the public universities' authorities reported that there is no special admission policy for the SEN students to enter to the IHLs [16]. It has also been reported that there is no good coordination between departments and faculties within the universities involved pertaining to the admission and the welfare of the SENs [16].

Secondly, providing tablets for SEN learners as well as improving technologies to cater their needs in Malaysian universities may contain financial implications. Currently, with limited financial capabilities, these plans are hardly feasible to be implemented in higher education.

Using Web 2.0 social software may require proper planning from the lecturers' part as it is prone to be abused by the students. Proper guidelines for students should be provided so that they could use the social software appropriately.

\section{ACKNOWLEDGMENT}

Special thanks to Ministry of Higher Education; Special Education Division, Ministry of Education; and Department of Social Welfare, Ministry of Women, Family and Community Development on their cooperation and assistance in completion of this study.

\section{REFERENCES}

[1] Education Act 1996, Act 550, Malaysia.

[2] Persons with Disabilities Act 2008, Act 685, Malaysia.

[3] Registration of Persons with Disabilities, Social Welfare Department, 2011.

[4] UNESCO, "The Salamanca Statement and Framework for Action on Special Needs Education," presented at the World Conference on Special Needs Education: Access and Quality, Salamanca, Spain, June 7-10, 1994.

[5] M. A. Manisah, M. Ramlee, and J. Zalizan, "An empirical study on teachers' perception towards inclusive education in Malaysia," International Journal of Special Education, vol. 21, issue 3, pp. 36-44, 2006.

[6] UNDO, UNESCO, UNICEF, and World Bank, "World Declaration on Education for All," presented at the World Conference on Education for All, Jomtien, Thailand, March 5-8, 1990.

[7] UNESCO, "The Dakar Framework for Action," presented at The World Education Forum, Dakar, Senegal, April 26-28, 2000.

[8] UN ESCAP, "Biwako Millenium Framework for Action: towards an inclusive, barrier-Free and rights-based society for persons with disabilities in Asia and the Pacific," presented at High-level Intergovernmental Meeting to Conclude the Asian and Pacific Decade of Disabled Persons, 1993-2002, Shiga, Japan, October 25-28, 2002

[9] Ministry of Women, Family and Community Development, Policies and Action Plans for Person with Disabilities, Kuala Lumpur: Ministry of Women, Family and Community Development, 2007.

[10] T. Hasnah, M. T. Arifin, M. Y. M. Hanafi, T. M. Mokhtar, and H. N Hazwani, "Knowledge and attitudes of non-disabled friends towards disabled students in on of Malaysian public universities - Pengetahuan dan sikap rakan sebaya terhadap pelajar kurang upaya di sebuah IPTA di Malaysia," ASEAN Journal of Teaching and Learning in Higher Education, vol. 2, issue 2, pp. 22-34, 2010. 
[11] T. Hasnah, M. Y. M. Hanafi, T. M. Mokhtar, and S. Norasuzaini, "Support and barriers faced by students with disabilities in one of Malaysian public universities - Sokongan dan halangan yang dihadapi oleh pelajar-pelajar kurang upaya di sebuah institusi pengajian tinggi di Malaysia," ASEAN Journal of Teaching and Learning in Higher Education, vol. 1, issue 2, pp. 18-29, 2009.

[12] M. S. Norshidah and P. A. D Mahani, "Support system for blind students in institutions of higher learning - Sistem sokongan untuk pelajar bermasalah penglihatan di institut pengajian tinggi," presented at the Persidangan Serantau Pendidikan Inklusif dan Pendidikan Kanak-kanak Berkeperluan Khas, 2009.

[13] A. Roslinda and A. A. Nor, "Inclusive education in Malaysian Institutes of Higher Learning: Experiences of special educational needs students," in Proc. Prosiding Seminar Internasional Pasca Siswazah Pendidikan Khas UKM-UPI Siri II 2012, Bangi, 2012, pp. 1163-1173.

[14] A. Roslinda, A. A. Nor, and I. B. Abu, "Towards inclusive education in Malaysian universities: Addressing the barriers, challenges and needs of special educational needs learners," Unpublished work, 2012.

[15] A. Roslinda, A. A. Nor, I. B. Abu, A. Halimaton, and L. K. Azman, "What do the disabled students need? A study on the needs of the special educational needs (SEN) learners in Malaysian public universities," presented at the 3rd International Conference on Education and Educational Psychology, Turkey, October 10-13, 2012.

[16] Ministry of Higher Education, "Disabled students: Support, Preparation and challenges in future - Pelajar kurang upaya: Bantuan, persediaan dan cabaran masa depan," Unpublished work, 2011.

[17] Assistive Technology Act of 2004, United States of America, Pub. L. No 108-364 1710

[18] D. H. Rose, W. S. Habour, C. S. Johnston, S. G. Daley, and L. Abarbanell. (2008). Universal design for learning in postsecondary education: Reflections on principles and their application. Journal of Postsecondary Education and Disability. [Online]. 19(2). pp. 135-150. Available: http://www.eric.ed.gov/PDFS/EJ844630.pdf

[19] Kentucky Assistive Technology Service Network, The Buck Starts Here: A Guide to Assistive Technology Funding In Kentucky, 12th Ed. Kentucky: Kentucky Assistive Technology Service Network, 2007.

[20] Microsoft Accessibility. (January 2012). [Online]. Available: http://www.microsoft.com/enable/default.aspx

[21] 5 Benefits of Tablets in Education. (October 2011). [Online]. Available: http://www.educationbulletinboard.com/2011/08/17/5-benefits-of-tabl ets-in-educaton/

[22] Apple. (May 2012). [Online]. Available: http://www.apple.com/accessibility/ipad/

[23] J. Lever-Duffy and J. B. McDonald, Teaching and Learning with Technology, 4th ed., 2011, ch. 4 and 12, Boston: Pearson.

[24] T. Franklin and M. V. Hermelen. (May 2007). Web 2.0 for Content for Teaching and Learning in Higher Education. [Online]. Available: http://www.ie-repository.jisc.ac.uk/148/1/web2-content-learning-and-t eaching.pdf

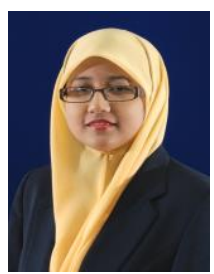

Roslinda Alias was born in the state of Selangor, Malaysia in 1978. She obtained her first degree in Bachelor of Human Sciences Hons. (Psychology) from International Islamic University of Malaysia in the year 2002. Later, in the same university, she pursued her Masters and was honored with a Masters of Education specializing in instructional technology in the year 2006. She is now in her third year of her $\mathrm{PhD}$ in Education at the Faculty of Education, Universit Teknologi MARA, Malaysia. Her specialization is in technology-supported learning for Special Educational Needs (SEN) learners in higher learning.

Currently, she is on her study leave for her $\mathrm{PhD}$ in Education. She started her career as a lecturer at the Faculty of Education, Universiti Teknologi MARA, Malaysia in year 2006. Then, in the year 2010 she has been promoted as a Senior Lecturer. She was a research officer at the Centre of Human Development and Applied Sciences (CERDAS) formerly known Applied Psychology Centre (APC), International Islamic University of Malaysia from 2002 to 2004. Her research interests are more in instructional technology specifically that is related to Special Educational Needs (SEN) learners without leave Educational Psychology areas behind.

Ms. Roslinda received a Young Lecturer Scheme Scholarship in the year 2002 from the Universiti Teknologi MARA, Malaysia to pursue her Masters degree. In the year 2010, the same university awarded her a scholarship to embark her PhD in Education.

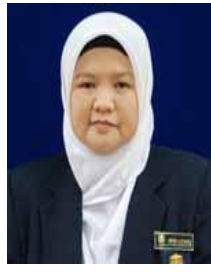

Nor Aziah Alias was born in the state of Pahang, Malaysia on the 8th of November, 1961. She earned her Bachelor and Master's degree in Physics from Indiana University, Bloomington in 1984 and 1986 respectively. She completed her Graduate Certificate in Open and Distance Learning in 1998 from the University of Southern Queensland, Australia. She later graduated with a doctoral degree in instructional technology from the International Islamic University, Malaysia in 2007

She is currently an Associate Professor of Instructional Technology and the Director of the i-Learn Centre at Universiti Teknologi MARA, Malaysia. She has also served as the instructional designer at the university's distance learning unit and as the Deputy Dean at the Faculty of Education. She is the editor of Instructional Technology Research, Design and Development with S. Hashim, and chapter contributors to 7 other books on technology and higher education including Improving Student Outcomes, Cases n Places: Global cases in educational and performance technology, and Cases on Globalized and Culturally Appropriate E-Learning: Challenges and Solutions. She also writes for journals such as Educational Technology and Society. Her current research interest is mainly in the areas of educational design research and ICT for development.

Dr. Nor Alias is a member of the Global E Learning Community and the Malaysian Association of Distance Education. She was awarded a fellowship under the Amy Mahan Research Fellowship Program in 2010; she was also the recipient of two Malaysian academic awards in 2007 and 2008. She sits on the review panel of journals such as Educational Technology and Society, International Journal of Education and Development using ICT, MERLOT Journal of Online Learning and Teaching, and IRRODL - Internationa Review of Research in ODL. She currently supervises local and international doctoral students and serves as external examiners at several Malaysian universities.

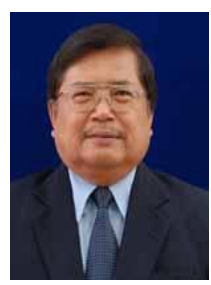

Abu Bakar Ibrahim was born in the state of Selangor, Malaysia in 1947. He holds a Certificate in Education from Universiti Pendidikan Sultan Idris, Malaysia in 1967 and Bachelors of Science in Education degree from Indiana Univeristy, USA in 1980. In 1981, he obtained his Masters degree in Education from Michigan State University, USA majoring in Curriculum and Instruction/TESOL and later in 1989 he obtained his $\mathrm{PhD}$ degree in Curriculum and Instruction from the same University

Currently, he is an Associate Professor of Education at the Faculty of Education, Universiti Teknologi MARA, Malaysia and holds the position of Deputy Dean of Research, Industry Linkages and Alumni. Prior to joining the Faculty of Education, he was the Head of Language Centre as well as lecturer at the same university. His area of expertise is Curriculum Development. He has presented papers nationally and internationally. In addition, he conducts courses in the area of curriculum development, instruction and adult learning.

Associate Prof. Dr Abu Bakar is a life member of the Malaysian Associate for Education and has held the position of Vice President, Assistant Secretary and Comitte Member as well as editor of the official journal of the Association, Suara Pendidik. He was awarded the Excellence Service Award in 2008, 1992 by the Faculty of Education and Academic Excellent Award in 1990 by Universiti Teknologi MARA.

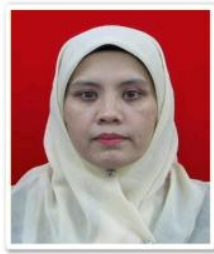

Jamizan Jalaluddin was born on 13th of March 1964 She earned her Diploma in Graphic Design from Universiti Teknologi MARA in the year 1986. A year later she obtained the Art Teacher Diploma from the same university. She pursued her Masters degree in De Montfort University Lachester UK and has been awarded the MA Art and Design Education.

Presently, she is a Senior Lecturer in Graphic and Head of Academia Special Community Network at the Universiti Teknologi MARA, Malaysia. Her experiences in dealing with Special Educational Needs SEN learners could not be denied as she was one of the pioneer teachers at the Vocational Secondary School for the Special (DEAF) in Shah Alam, Selangor, Malaysia in the year 1988. Her last position at the Vocational Secondary School for the Special (DEAF) was Assistant Principal (Student Affairs) before she joined the Universiti Teknologi MARA as a lecturer in the year 2001. Besides Art and Design, her research interest is also on special education particularly deaf education.

Ms. Jamizan Jalaluddin is a member of the Malaysian Federation of the DEAF (MFD) and Malaysian Design Council. She has contributed a lot in catering for the needs of SEN learners especially in the Universiti Teknologi MARA, Malaysia. 